\title{
RECENT DEVELOPMENTS IN INDIANA FAMILY LAW: OCTOBER 2018 TO SEPTEMBER 2019
}

\author{
RENA SEIDLER ${ }^{*}$
}

This Article considers the notable developments in Indiana family law during the survey period of October 1, 2018, to September 30, 2019. The published appellate cases surveyed in this Article concern property division upon divorce, parenting time and visitation, child custody, child support, adoption and paternity, CHINS and the termination of parental rights, and jurisdiction and procedure.

\section{PROPERTY DIVISION}

One property division matter that arose during the survey period stemmed from a wife's appeal of the trial court including the husband's pension and valuation of survivor benefits of said pension as marital assets in their divorce proceedings. ${ }^{1}$ The wife alleged that the pension and survivor benefits should be considered separate from the marital estate, and therefore not contributing to the distribution of estate assets. ${ }^{2}$ The appellate court affirmed the trial court's decision to include these assets in the marital estate, finding that the trial court did not clearly err in concluding that the parties had never intended these assets to be separate from the marital estate. ${ }^{3}$

In a case where the parties were only married for twenty-four days, the trial court granted the wife $\$ 35,000$ for the sale of a home purchased during the marriage and the remainder of the net proceeds of the sale to the husband. ${ }^{4}$ The wife appealed, stating that the net proceeds should be divided evenly, rather than the husband receiving the bulk of the proceeds. ${ }^{5}$ In affirming the trial court's decision, the appellate court concluded that the trial court did not abuse its discretion in its holding, when the husband had solely paid for the residence, its upkeep, and all utilities associated with the residence. ${ }^{6}$

In another case, a wife appealed the trial court's decision to include an equalization payment from the husband within six years of their divorce, alleging that the trial court was improper in not including interest on the payments, so long as payments were made in a timely manner. ${ }^{7}$ The wife contended that interest was appropriate as it took into consideration inflation and incentivized timely payments. ${ }^{8}$ While the appellate court recognized some merit to the wife's argument, it affirmed the trial court's decision based on the facts and

* Research and Instructional Services Librarian, Indiana University Robert H. McKinney School of Law.

1. Bock v. Bock, 116 N.E.3d 1124 (Ind. Ct. App. 2018).

2. Id. at 1126 .

3. Id. at 1128 .

4. Rose v. Bozeman, 113 N.E.3d 1232, 1233-34 (Ind. Ct. App. 2018).

5. Id. at 1234 .

6. Id. at $1233,1235-36$.

7. Cohen v. Cohen, 120 N.E.3d 1083 (Ind. Ct. App. 2019).

8. Id. at 1086 . 
circumstances of the case and a previous holding by the Indiana Supreme Court ${ }^{9}$ on a factually similar matter. ${ }^{10}$

When a husband failed to make installment payments under the parties' personal settlement agreement ("PSA") entered into during their divorce proceedings, the wife requested selling the family farm to meet the payment obligations. ${ }^{11}$ Under the PSA, the parties had agreed that the husband would keep the family farm and make equalization payments of over $\$ 300,000$ to the wife. ${ }^{12}$ The trial court granted the wife's request, and she entered into a contract to sell the farm. ${ }^{13}$ The husband subsequently filed a motion to stay the sale, stating that he had found buyers to purchase a portion of the property to meet his obligations and that would allow him to keep a portion of the property, which the trial court denied, and the husband appealed. ${ }^{14}$ The appellate court denied the husband's request to stay the final judgment of possession, and the husband then filed this action, arguing that the trial court had abused its discretion in finding that the wife had a judgment lien against the farm and denying the motion to rescind the sale. ${ }^{15}$ The appellate court concluded, in parts pertinent to family law, 1) that the wife had a judgment lien against the farm but not a dissolution security interest, 2) that both parties had the right to sell the farm, and 3) that the rescission of the wife's sale of the home was not warranted. ${ }^{16}$

\section{PARENTING TIME \& VISITATION}

Regarding parenting time case law during the survey period, an Indiana appellate court affirmed a trial court's decision granting sole legal and primary physical custody of the children to the mother. ${ }^{17}$ The father appealed on the grounds that the trial court wrongfully considered his active-duty status in the United States Air Force in making its decision. ${ }^{18}$ The appellate court agreed that the trial court was erroneous in considering father's active-duty status, but nevertheless affirmed, noting that deference was given to the trial court and that the trial court had made sufficient findings and conclusion based on the multitude of other evidence considered. ${ }^{19}$

9. Rovai v. Rovai, 912 N.E.2d 374, 376 (Ind. 2009), wherein the Court concluded, "We see little reason for transporting the post-judgment interest statute into the equitable world of dissolutions[.]"

10. Cohen, 120 N.E.3d at 1089.

11. Kobold v. Kobold, 121 N.E.3d 564 (Ind. Ct. App. 2019).

12. Id. at 567.

13. Id.

14. Id. at 568-70.

15. Id. at 567.

16. Id. at 576-77.

17. Purnell v. Purnell, 131 N.E.3d 622 (Ind. Ct. App. 2019).

18. Id. at 623 .

19. Id. at 629 . 


\section{CHILD CUSTODY}

One significant custody that arose during survey period focused on a father's emergency petition for modification of physical custody of a child when the mother left the three-year-old child unattended on numerous occasions while sleeping after using marijuana. ${ }^{20}$ The child wandered onto an upper level balcony on one occasion and on another was found walking several blocks from the mother's residence. ${ }^{21}$ While the trial court did not find the situation to warrant an emergency, the court nevertheless found that the child's escaping on numerous occasions while the mother had been using substances warranted a change in physical custody. ${ }^{22}$ On appeal, the mother argued that a change in physical custody was not warranted 1) when the trial court had found that the situation was not an emergency; 2) when the child did not suffer any harm while in her care; and 3 ) because use of marijuana is not enough to modify child custody. ${ }^{23}$ The appellate court affirmed the trial court's decision, finding that the mother's arguments were not supported by cogent reasoning. ${ }^{24}$

\section{CHILD SUPPORT}

There were several child support cases of note decided during the survey period. In one such case, the father had a weekly income which included a substantial annuity from the state of Illinois. ${ }^{25}$ The father was also a professional gambler, and the trial court determined the father's weekly child support obligation by adding his annuity and averaging his previous two years of gambling earnings in determining. ${ }^{26}$ The father appealed, arguing that the court should determine his gambling earnings obligation as a flat percentage of the earnings. ${ }^{27}$ The appellate court affirmed, finding that the trial court did not abuse its discretion. ${ }^{28}$

In another case, a trial court reduced the father's child support obligation below what the parties had agreed to. ${ }^{29}$ For many years prior to the mother's petition for child support, the father had been paying child support upon an amount agreed to privately between the parties. ${ }^{30}$ During the trial, both parties acknowledged that the father had SSR benefits that were going directly to the

20. Smith v. McPheron, 120 N.E.3d 226 (Ind. Ct. App. 2019).

21. Id. at 230 .

22. Id. at 231 .

23. Id.

24. Id. at 231-32.

25. In re Paternity of T.M.-B, 131 N.E.3d 614 (Ind. Ct. App.), trans. denied sub nom. Bush v. Mapletoft, 137 N.E.3d 918 (Ind. 2019).

26. Id. at 618 .

27. Id. at 619 .

28. Id. at 620 .

29. Barrand v. Martin, 120 N.E.3d 565 (Ind. Ct. App. 2019).

30. Id. at 567 . 
child in addition to $\$ 180$ per week orally agreed upon by the parties. ${ }^{31}$ The court interpreted statements by father as his intent to pay the previously agreed upon amount of child support, and entered an order confirming that amount, without referring to the SSR benefits. ${ }^{32}$

The father subsequently filed a motion to correct errors, contesting that his $\$ 180$ per week child support previously agreed to orally by the parties, and subsequently included in the order by the trial court, was not intended to be in addition to the SSR contribution. ${ }^{33}$ The trial court concluded that parties had a vague, unenforceable child support agreement and clarified the order to $\$ 57$ in child support per week, taking into account the father's SSR contribution. ${ }^{34}$ The mother appealed, arguing that she and the father had a contract for the father to pay the $\$ 180$ per week in addition to the SSR benefits, regardless of whether this amount exceeded the father's child support obligation. ${ }^{35}$ The appellate court found that the trial court did not err in its determination that the parties had an unenforceable agreement based on different understandings of the agreed upon child support, and affirmed the trial court's order. ${ }^{36}$

In one case of child support for an adult child, a mother appealed a trial court's decision obligating her to continue paying child support after the child turned nineteen, when the child had a full scholarship to college and no related fees for his university attendance. ${ }^{37}$ In its review of this matter, the appellate court noted that the child was over eighteen and was capable of supporting himself. ${ }^{38}$ The appellate court overruled the trial court, finding that the mother's obligation to pay child support terminated when the child turned nineteen, pursuant to I.C. $31-16-6-6 .^{39}$

In another such case, after a divorce, a father moved that a mother be required to contribute to their adult daughter's post-secondary education expenses. ${ }^{40}$ The father appealed the trial court's holding that the daughter repudiated the mother and relieved the mother from the expenses. ${ }^{41}$ At the time the father sought the mother's contribution to these expenses, the child was eighteen and had refused to see the mother for over two years, despite the mother's repeated attempts to be involved in the child's life. ${ }^{42}$ During the trial, the daughter testified that she was indifferent to having a relationship with the mother, and that she would not

31. Id. at 568 .

32. Id.

33. $I d$.

34. Id. at 570 .

35. Id. at 572 .

36. Id. at 573 .

37. Baker v. Grout, 116 N.E.3d 475, 476 (Ind. Ct. App. 2018).

38. Id. at 477-78.

39. Id. at 478 .

40. Messner v. Messner, 118 N.E.3d 64, 66 (Ind. Ct. App.), trans. denied 127 N.E.3d 227 (Ind. 2019).

41. Id. at $67-68$.

42. Id. at 66 . 
consider a relationship with the mother unless the mother ended her current romantic relationship. ${ }^{43}$ The trial court concluded that the child had repudiated the mother. ${ }^{44}$ The appellate court concluded that the trial court had used the correct standard in finding that the child repudiated the relationship, and affirmed the trial court. ${ }^{45}$

\section{PATERNITY \& ADOPTION}

Several paternity and adoption cases arose during the survey period. In one such paternity matter, the appellate court affirmed the trial court's decision establishing putative father's paternity, per the father's request, while child was the subject of a CHINS proceeding. ${ }^{46}$ The mother appealed the trial court's paternity judgment arising from the CHINS proceeding. ${ }^{47}$ During the CHINS proceeding, the mother testified that the father was the child's father and notified the father for the first time that he had a child, and then the father immediately filed a petition to establish paternity and for custody during the CHINS proceeding. ${ }^{48}$ The mother appealed the paternity finding in part, arguing that there was an insufficiency of evidence to establish the paternity of the child. ${ }^{49}$ The appellate court affirmed the decision of the trial court, noting that the mother's testimony was evidence weighing in favor of the father, and thus the trial court's paternity determination was not clearly erroneous. ${ }^{50}$

In another case, a mother and biological father jointly sought to establish paternity, with the child's legal father being joined out of necessity. ${ }^{51}$ In this case, the mother had a child in 2009 and shortly thereafter executed a paternity affidavit with the legal father. ${ }^{52}$ In 2010, the mother and biological father's relationship ended; several months later, the legal father filed a petition to establish paternity, which the trial court granted, awarding joint legal custody and primary physical custody to the mother. ${ }^{53}$ In 2017 , the legal father filed a motion for modification of parenting time and to clarify several other custody and visitation matters. ${ }^{54}$ At that point, the mother reached out to the biological father and after establishing that he was the biological father, they filed the petition to

43. Id. at $66-67$.

44. Id. at 67 .

45. Id. at 70 .

46. In re Paternity of K.H., 116 N.E.3d 504, 514 (Ind. Ct. App. 2018), trans. denied sub nom. Harris v. Cochran, 123 N.E.3d 144.

47. Id. at 506 .

48. Id. at 507.

49. Id. at 511 .

50. Id. at 512 .

51. Litton v. Baugh, 122 N.E.3d 1034, 1036 (Ind. Ct. App. 2019).

52. $I d$.

53. Id.

54. Id. 
establish paternity. ${ }^{55}$ The trial court dismissed the petition. ${ }^{56}$

\section{GRANDPARENT VISITATION}

After several years with no significant developments in Indiana, grandparent rights cases again made an appearance in the survey period. In one such case, the appellate court addressed grandparent rights of visitation and whether a grandparent visitation order over children born out of wedlock survived after the children were legitimized by the marriage of the children's biological parents. ${ }^{57}$ At issue was a 2011 visitation order that had been granted to paternal grandmother under the out-of-wedlock section of the Indiana Grandparent Visitation Act, Indiana Code section 31-17-5-1(a)(3). ${ }^{58}$ The parents married in 2013 and sought to dismiss the grandparent visitation order on the grounds that the order did not survive the children being legitimized. ${ }^{59}$ The trial court disagreed and the parents appealed. ${ }^{60}$ In reviewing and reversing the trial court's decision, the appellate court examined the construction of the statute. ${ }^{61}$ The appellate court noted that the statute specifically addresses two manners in which such an order predicated on children being born our-of-wedlock survives, and as legitimacy is not specifically listed, the appellate court concluded that such an order was not intended to survive in this instance. ${ }^{62}$

In another case, the grandparents sought guardianship over the children, with supervised visitation for the parents. ${ }^{63}$ During the trial, the father did not consent to the guardianship and filed a motion for automatic change of judge, which the trial court denied, granting the grandparent's petition. ${ }^{64}$ The trial court granted the father visitation, "as agreed upon by the parties," despite the grandmother testifying that she did not speak to father and intended to allow visitation only if the children requested it. ${ }^{65}$ The appellate court reversed and remanded, finding that in requiring the parties to agree on visitation, the trial court had erroneously given the grandparents control over whether visitation would occur. ${ }^{66}$

\section{CHINS AND THE TERMINATION OF PARENTAL RIGHTS}

The number of CHINS cases in Indiana remains relatively unabated for yet another year. In one such case, parents appealed a trial court decision that their

55. Id. at 1037 .

56. Id. at 1035 .

57. Campbell v. Eary, 132 N.E.3d 413 (Ind. Ct. App. 2019).

58. Id. at 415 .

59. Id.

60. Id.

61. Id. at 415-16.

62. Id. at 416-17.

63. Blankenship v. Duke, 132 N.E.3d 410 (Ind. Ct. App. 2019).

64. Id. at $411 \mathrm{n} .1$.

65. Id. at 412 .

66. Id. at 413 . 
child was a child in need of services ("CHINS") ${ }^{67}$ The parents allege that the trial court erred in its decision because the child's needs were not unmet and there was no evidence the child was seriously endangered in the parents' care.$^{68}$ In response, DCS asserted that the child was a CHINS, as the mother had unspecified mental health issues and was admittedly not taking her prescribed medication, and emphasized a doctor's opinion that the mother's mental health issues "could" interfere in parenting matters. ${ }^{69}$ Similarly, DCS relied upon the doctor's opinion that the father's low intellect "could interfere in parenting." ${ }^{, 70}$ Finally, DCS relied on the parents' homeless state at the time of the child's birth as evidence that the child was a CHINS, despite the parents having housing at the time the child was removed from them. ${ }^{71}$ The appellate court reversed the trial's court's decision, noting that a CHINS determination could not rely on conditions that no longer existed at the time of removal and that the mere potential of parenting issues arising from the parents' mental states was insufficient to warrant finding the child to be a CHINS. ${ }^{72}$

In another CHINS case, a mother appealed the trial court finding her child to be a CHINS. ${ }^{73}$ The child had been found to be a CHINS two years prior to this CHINS proceeding, but the mother had complied with all necessary, management, mental health treatment, and other ordered steps, leading to a reunification with the child and a termination of the state's wardship. ${ }^{74}$ In this instance, the child was adjudicated a CHINS based on mother's ongoing mental health struggles, an incarceration leaving the child without care, and the child's statements that he does not get enough to eat when with his mother. ${ }^{75}$ The mother appealed, arguing that DCS has failed to establish that the child was seriously impaired or endangered by her actions when a case manager testified that she was voluntarily engaged in substance abuse treatment, taking prescribed medications for the mental health matters, and no longer incarcerated. ${ }^{76}$ The appellate court reversed, finding that DCS presented insufficient evidence to show by a preponderance of the evidence that the child was a CHINS. ${ }^{77}$

In finding a child to be a CHINS, a trial court found that a child's statements were sufficiently reliable to be admissible. ${ }^{78}$ At age four, the child alleged that her father was molesting her. ${ }^{79}$ The mother clearly stated that she did not believe the

67. In re L.N., 118 N.E.3d 43 (Ind. Ct. App. 2019).

68. Id. at 48 .

69. Id.

70. Id.

71. Id. at 49 .

72. $I d$. at 50.

73. C.M. v. Ind. Dep't of Child Servs., 130 N.E.3d 1149 (Ind. Ct. App. 2019).

74. Id. at 1151 .

75. Id.

76. Id. at 1154 .

77. Id. at 1158 .

78. In re A.M., 121 N.E.3d 556 (Ind. Ct. App 2019).

79. Id. at 558 . 
child, and child was subsequently found to be a CHINS. ${ }^{80}$ In its finding, the trial court admitted and considered child's testimony after a child's hearsay hearing, along with several other factors. ${ }^{81}$ The parents appealed, challenging child's hearsay statements. The appellate court affirmed, finding that the trial court acted within its discretion in admitting the hearsay statements, noting that the trial court has statutory authority to admit hearsay statements and that parents' objection to the admission was not based on any impropriety in their admission, but rather they objected to the content of the admission. ${ }^{82}$

In another case, a mother appealed her four children being found to be CHINS based on her homelessness and methamphetamine use. ${ }^{83}$ On appeal, the mother alleged that the trial court erred in adjudicating the children to be CHINS. ${ }^{84}$ During the trial, there was ample testimony from various DCS employees that mother had not tested positive for any drugs since the children were removed from her custody, that she was financially providing for all of their needs, and that she was attending all parental visitations and bonding with the children during these visitations. ${ }^{85}$ Mother additionally testified that she had obtained housing and that the housing had been inspected and approved as safe and appropriate for the children ${ }^{86}$ Nevertheless, the trial court found the children to be CHINS. The appellate court reversed, noting that the court, "should consider the family's condition not just when the case was filed, but also when it is heard," and that the trial court had failed to appropriately consider the facts at the time of the trial. ${ }^{87}$

The appellate court affirmed a trial court finding that a child was a CHINS by a preponderance of the evidence presented. ${ }^{88}$ The child was removed from the home after the mother's boyfriend physically abused another of the mother's children, resulting in the death of that child. ${ }^{89}$ Evidence put forth during the trial showed that the child at issue witnessed the boyfriend physically abusing the mother; that the mother did not notice abuse of the other child before that child died in her custody from abuse by the boyfriend, that the mother had failed to address domestic violence issues since the death of her child; and that at the time of adjudication, the mother was facing criminal charges resulting to a no contact order with the child..$^{90}$ The appellate court affirmed the trial court's holding, noting that this evidence was sufficient to support the CHINS adjudication. ${ }^{91}$

80. Id.

81. Id. at 559.

82. Id. at 560-61.

83. In re A.R., 121 N.E.3d 598 (Ind. Ct. App. 2019).

84. Id. at 600 .

85. Id. at 601 .

86. Id.

87. Id. at 603 .

88. K.A.H. v. Ind. Dep't of Child Servs., 119 N.E.3d 1115 (Ind. Ct. App. 2019).

89. Id. at 1118 .

90. Id. at 1119.

91. Id. 
In a termination of parental rights matter, a father appealed the termination of parental rights to his child when he failed to demonstrate a willingness to care for the newborn child when mother was unable to provide the child a home that was stable and free of substance abuse. ${ }^{92}$ During the nearly two years of proceedings prior to the father's parental rights being terminated, the father failed to maintain consistent involvement in DCS proceedings, stated to DCS that he was unable to be a competent father, was arrested for possession of methamphetamine and conspiracy to commit robbery, was sentenced to nine years in the Department of Correction ("DOC"), and attempted to execute a valid document consenting to a family member adoption of the child. ${ }^{93}$ The trial court terminated the father's parental rights, finding that he had not attempted to establish a relationship with the child from or since birth, that attempts to reunite the child with the father had failed, that the father had over a year of incarceration left, and that the child's adoption by the long-term foster family was in the best interest of the child. ${ }^{94}$ The appellate court affirmed the trial court's holding, noting that the father did not dispute the evidence presented at the trial. ${ }^{95}$

\section{JURISDICTION \& PROCEDURE}

There were many significant jurisdiction and procedural matters that arose during year in review. In one procedural matter, the Supreme Court reviewed an appellate court's finding ${ }^{96}$ that the mother had waived a res judicata claim in a CHINS matter by not raising it to the trial court. ${ }^{97}$ In that matter, a DCS CHINS petition was dismissed without prejudice and a subsequent, and ultimately successful, DCS petition with nearly identical allegations was filed the following day. ${ }^{98}$ The mother appealed under the doctrine of res judicata, and the appellate court dismissed her appeal on the basis that she had failed to bring it during the trial. ${ }^{99}$ While the Supreme Court agreed with the appellate court that the mother had waived her res judicata claim, it also noted that application of the doctrine of res judicata

could prevent repeated filings by DCS with no new factual basis until one petition finally sticks. It could also prevent repetitive litigation of issues that have been or could have been decided in an initial CHINS filing. As such, application of this doctrine to CHINS proceedings encourages DCS to fully investigate and present a more complete picture of the type of alleged conduct underpinning a CHINS petition. After all, trial courts certainly do not suffer when an issue is fully briefed and

92. R.L.-P., 119 N.E.3d 1098, 1100 (Ind. Ct. App. 2019).

93. Id. at $1100-01$.

94. Id. at 1102.

95. Id. at 1105 .

96. In re Eq.W., 106 N.E.3d 536, 539-40 (Ind. Ct. App. 2018).

97. In re Eq.W., 124 N.E.3d 1201, 1205 (Ind. 2019).

98. Id.

99. Id. at 1207. 
supported by evidence..$^{100}$

In another procedural matter that arose from a CHINS case, DCS's appeal of the case was impacted by the holding addressed above in the Indiana Supreme Court case in In re Eq.W. ${ }^{101}$ In this matter, a CHINS petition was dismissed without prejudice and a subsequent DCS petition, which included some new allegations, was also dismissed, with the court finding that only the new allegations should be considered in the second petition. ${ }^{102}$

DCS appealed, on the grounds that they could rely on both the new and original allegations. ${ }^{103}$ The mother did not file any response to the appeal, including any claim of res judicata. ${ }^{104}$ While the supreme court's decision came out before DCS appealed in this matter, the appellate court concluded that because the mother did not make any allegation of res judicata during the second CHINS proceeding, and the second CHINS petition included new allegations, there was no need to conduct an $E q . W$. analysis. ${ }^{105}$ Thus, the mother's appeal on the basis of res judicata was denied. ${ }^{106}$

A mother brought an interlocutory appeal in a CHINS matter, asserting that the CHINS finding by the trial court should be dismissed because the CHINS factfinding hearing was not completed within sixty days (or 120 with party consent) after the filing of the petition. ${ }^{107}$ DCS and the mother agreed to a factfinding hearing on January 28, 2018. ${ }^{108}$ The mother filed a motion to continue the hearing as a non-contested factfinding hearing on January 17, 2018, stating that she and DCS had reached an agreement and asking that the hearing be conducted within thirty to forty-five days in the future. ${ }^{109}$ The hearing took place on February 26, 2018, the child was found to be a CHINS. ${ }^{110}$ The mother filed this interlocutory appeal on October 26, 2018. ${ }^{111}$ The appellate court affirmed the trial court, noting that per the mother's argument, requesting a dismissal postadjudication would essentially be a substitution for an appeal. ${ }^{112}$

In another procedural issue, stemming from the Paternity of K.H. matter discussed supra, the trial court established paternity at the request of the child's father, who learned about the child for the first time during a CHINS proceeding

100. Id. at 1211 .

101. In re R.L., 133 N.E.3d 173, 174 (Ind. Ct. App. 2019).

102. Id. at 175 .

103. Id.

104. Id.

105. Id. at $175-76$.

106. Id. at 176 .

107. In re J.S., 130 N.E.3d 109, 110 (Ind. Ct. App. 2019).

108. Id. at 111 .

109. Id.

110. Id.

111. Id. at 112 .

112. Id. at 113 . 
regarding the mother's care of the child. ${ }^{113}$ The mother appealed the paternity finding, in part, on the grounds that only DCS could initiate a paternity finding in a CHINS proceeding. ${ }^{114}$ The appellate court found no merit to the mother's argument. ${ }^{115}$

When a father objected the mother's notice of intent to relocate with their child to another city, the trial court denied the mother's request and awarded primary physical custody and sole legal custody to the father. ${ }^{116}$ The mother appealed the award of sole legal custody to the father, as legal custody was not at issue in the case. ${ }^{117}$ The father agreed that he did not specifically request a change in legal custody, but legal custody is always at issue when one parent files a notice of intent to relocate and the other parent objects, pursuant to Indiana Code section 31-17-2.2. ${ }^{118}$ The appellate court reversed, finding that for the trial court to have given the father sole legal custody, the father must have specifically requested a modification of legal custody. ${ }^{119}$

In a case under appeal on an allegation of a violation of procedural due process rights, a father appealed the termination of his parental rights during a hearing in which he did not appear personally or by counsel, arguing that the court was required to appoint counsel for him. ${ }^{120}$ The father was incarcerated during the time of the CHINS case and the termination of his parental rights. ${ }^{121}$ Throughout the case, the father expressed to DCS that he wanted to be involved in the case, but made no effort to appear at any hearing or obtain counsel. ${ }^{122}$ In affirming the trial court decision, the appellate court noted that the father needed to have only phoned into the hearings or to have made a phone call to have an attorney appointed, but he made no attempt at either. ${ }^{123}$ Moreover, under the doctrine of parens patriae the court must look out for the interests of both the parent and the child, and therefore the risk of error is low. ${ }^{124}$

113. In re: Paternity of K.H., 116 N.E.3d at 511.

114. Id.

115. Id. at 510 .

116. In re Paternity of W.R.H., 120 N.E.3d 1039, 1040 (Ind. Ct. App. 2019).

117. Id.

118. Id.

119. Id. at 1043 .

120. Termination of Parent-Child Relationship of X.S., 117 N.E.3d 601, 603 (Ind. Ct. App. 2018).

121. Id.

122. Id. at 604 .

123. $I d$. at 607 .

124. Id. at 608 . 